\title{
Antidesiccant Compounds Improve the Survival of Bare-root Deciduous Nursery Trees
}

\author{
John M. Englert ${ }^{1}$, Keith Warren ${ }^{2}$, Leslie H. Fuchigami ${ }^{3}$, and Tony H.H. Chen ${ }^{4}$ \\ Department of Horticulture, 2042 Cordley Hall, Oregon State University, Cowallis, OR 97331-291 I
}

Additional index words. postharvest handling, desiccation tolerance, water stress, antitranspirants, Norway maple, Acer platanoides, Washington hawthorn, Crataegus phaenopyrum, red oak, Quercus rubra

\begin{abstract}
Desiccation stress during the postharvest handling of bare-root deciduous trees can account for dieback and poor regrowth after transplanting. Desiccation tolerance of three bare-root deciduous hardwood species was determined at monthly harvest intervals from Sept. 1990 through Apr. 1991. Among the three species tested red oak (Quercus rubra L.) was most tolerant to desiccation, followed by Norway maple (Acer platanoides L.) and Washington hawthorn (Crataegus phaenopyrum Medic.). Maximum desiccation tolerance of all three species occurred during the January and February harvests. Of 20 film-forming compounds tested, the antidesiccant Moisturin was the most effective in reducing water loss from bare-root trees during desiccation stress and in improving survival and plant performance during re-establishment in the laboratory, greenhouse, and field. Moisturin-treated plants lost up to $80 \%$ less water than untreated plants. Washington hawthorn seedlings treated with Moisturin before severe desiccating conditions had the highest survival, lowest dieback/plant, and highest root growth ratings. The results indicate that Moisturin is an effective means of overcoming postharvest desiccation stress in desiccation sensitive plants, such as Washington hawthorn.
\end{abstract}

Nursery-grown deciduous ornamental trees are commonly dug bare-root during the fall/winter season and are either heeled in sawdust outdoors or placed bare-root in cold storage until shipping or planting. Reducing water loss during the handling of bare-root nursery plants minimizes desiccation stress and improves the survival of conifers (Lefevre et al., 1991) and deciduous trees (Insley and Buckley, 1985; Kozlowski and Davies, 1975; Murakami et al., 1990). Species such as Betula pubescens J.F. Ehrh. (Insley and Buckley, 1985) and Washington hawthorn (Murakami et al., 1990) are generally considered to be more difficult to handle due to a greater sensitivity to water loss. Some studies have suggested that storability and transplant success of desiccation sensitive species are improved when plants are harvested at times of the year when desiccation tolerance is highest (Murakami et al., 1990; Ritchie et al., 1985).

Cultural practices used in the nursery industry to prevent or reduce desiccation stress, including wrapping plants in polyethylene (Lefevre et al., 1991) or dipping plant roots in mud slurries (Mulling and Bunting, 1979), are often messy and difficult to perform. Direct application of film-forming compounds also has been used to reduce water loss from woody plants. Waxes have traditionally been used on rose canes during storage and shipping (Lyle, 1955; Tukey and Brase, 1931). Waxes and antitranspirants have been somewhat effective in reducing water loss through the bark of defoliated hardwood seedlings and in improving transplant success (Sulaiman, 1968). Antitranspirants applied to the foliage of bare-root conifer seedlings have in some cases reduced water

Received for publication on 15 May 1992. Accepted for publication 27 Aug. 1992 Oregon Agricultural Experiment Station Technical Paper no. 9898. We thank Ted Mackey and Lisa Pace for their technical assistance, J. Frank Schmidt \& Son Co. for providing the plant materials, and the suppliers of antidesiccant compounds for providing samples used in this study. This project was supported in part by a grant from the Oregon Nursery Advisory Council. No endorsement or discrimination of products mentioned is made by Oregon State Univ. The cost of publishing this paper was defrayed in part by the payment of page charges. Under postal regulations, this paper therefore must be hereby marked advertisement solely to indicate this fact. Graduate Research Assistant.

Staff Horticulturist, J. Frank Schmidt \& Son Co., Boring, OR 97009.

${ }^{3}$ Professor.

${ }^{4}$ Associate Professor loss, but at the same time, reduced plant performance (Simpson, 1984).

Convenient methods of reducing water loss during postharvest handling of bare-root plants and improving the survival and performance of plants during establishment would be useful to the nursery industry and consumers. Some products on the market might be effective in reducing water loss from bare-root plants, including antitranspirants used on foliage, waxes used on fruits and vegetables, and several new compounds that have not been adequately tested.

The objectives of this study were to determine the seasonal variation of tolerance of bare-root plants to desiccation stress, to test the effects of antidesiccant compounds in reducing water loss during postharvest handling, and to improve the survival of bareroot nursery trees during plant re-establishment.

\section{Materials and Methods}

Plant materials. Three different sets of plants were obtained from the J. Frank Schmidt Nursery, Boring, Ore.: 1) One-year-old seedlings of Washington hawthorn, Norway maple, and red oak were harvested bare-root monthly from 17 Sept. 1990 to 12 Apr. 1991. Seedlings were hand defoliated when necessary. Excess soil was washed from the roots and the seedlings (roots and stems) were placed in polyethylene bags (film $0.035 \mathrm{~mm}$ thick) and transported to Corvallis. Plants were held overnight at $0 \mathrm{C}$ for use in desiccation tolerance experiments the following day, or were stored at $0 \mathrm{C}$ for up to 2 months until used in antidesiccant studies. 2) Two-year-old Washington hawthorn seedlings were harvested in early Jan. 1991, and stored at $1 \mathrm{C}$ and ca. 98\% relative humidity (RH). In Feb. 1991, they were placed in polyethylene bags, transported to Corvallis, and held at 0C until Apr. 1991. 3.) Multistemmed Washington hawthorn trees, $1 \mathrm{~m}$ high, were harvested in late Dec. 1990 and stored at $1 \mathrm{C}$ and ca. $95 \%$ RH until May 1991. They were then used for field testing of antidesiccant compounds.

Evaluation of desiccation tolerance. Desiccation studies consisted of air-drying defoliated bare-root plants on a laboratory bench at $23 \pm 2 \mathrm{C}$ and $47 \pm 5 \%(\mathrm{RH})$ for $0,1,2,4,8,12,24$, or $48 \mathrm{~h}$. 
Table 1. Types and sources of film-forming materials tested.

\begin{tabular}{llll}
\hline \hline Compoound & Dilution $^{2}$ & Type of compound & Supplies \\
\hline Antitranspirants & $1: 100,1: 40$ & Acrylic polymer & \\
AntiStress 2000 & $1: 10$ & Acrylic polymer & Polymer Ag, Fresno, Calif. \\
Clearspray & pre-mix & NA & W.A. Cleary Chemical Corp., Somerset, N.J. \\
Cloudcover & $1: 20$ & Hydrocarbon wax emulsion & Easy Gardener, Waco, Texas \\
Folicote & $1: 7$ & Acrylic co-polymer & Mycogen Corp., San Diego \\
ForEverGreen & $1: 4$ & NA & Kirk Co., Wautoma, Wis. \\
Needlehold & $1: 40$ & Terpenic polymer & Miller Chemical Corp., Hanover, Pa. \\
VaporGard & $1: 5$ & Terpenic polymer & WiltPruf Products, Greenwich, Conn. \\
WiltPruf & & & \\
Waxes/preservatives & $1: 5$ & NA & ATOCHEM North America, Agrochemicals \\
Decco A & & & Divsion, Monrovia, Calif. \\
& $1: 2$ & NA & ATOCHEM \\
Decco C & --- & NA & ATOCHEM \\
Decco D & --- & Carnauba wax, shellac & Agri-Tech, Yakima, Wash. \\
Fresh-Cote CW1 & --- & Shellac (alcohol base) & Agri-Tech \\
Fresh-Cote 214 & $1.75 \%(w / v)$ & Sucrose esters, glycerides & Inotek International Corp., Mentor, Ohio \\
Semperfresh & --- & Carnauba wax & Shield Brite Corp., Kirkland, Wash. \\
Shield Brite AP-40 & --- & Carnauba wax & Shield Rite Corp. \\
Shield Brite AP-50C & --- & Polyethylene emulsion & Shield Brite Corp. \\
Shield Brite C-280 & --- & Carnauba wax & FMC Corp., Riverside, Calif. \\
StaFresh 819 & & &
\end{tabular}

Latex coatings

BPC \#1 $1^{y}$

Moisturin ${ }^{x}$

--- Acrylic polymer

1:1, 1:3 Latex emulsion

Burke's Protective Coatings, Washougal, Wash. Burke's Protective Coatings

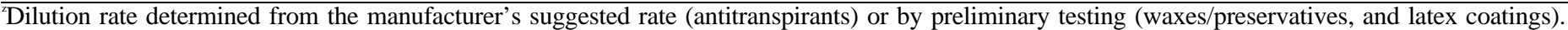
Dilutions made with distilled water.

'Experimental name used in this study.

${ }^{x}$ Experimental formulation. Refer to product label for current recommended dilution rates.

$\mathrm{NA}=$ product information not available.

Water loss was determined gravimetrically and was expressed on a fresh weight basis. After air-drying, plants were potted into 3.8liter plastic pots in a medium of 1 peat : 1 loam soil : 1 washed sand : 2 screened \#8 pumice (by volume) and maintained in a greenhouse at $27 / 18 \mathrm{C}$ (day/night). After 60 days, percent survival was estimated (number of plants that grew/total number of plants in a treatment $)$ and percent dieback/plant $(0 \%=$ no stem dieback, $50 \%$ $=$ budbreak from the base to the middle of the stem, $90 \%=$ budbreak at the base of the stem, and $100 \%=$ no budbreak, plant was dead). Root growth was evaluated and assessed by the following scale: $0=$ no new root growth; $1=$ new primary roots $<10 \mathrm{~mm}$ long; 2 = primary roots $>10 \mathrm{~mm}$ long, secondary roots beginning to form; $3=$ secondary roots well-developed, tertiary roots beginning to form; 4 = root ball forming; and 5 = root mass well developed. Desiccation tolerance was expressed as a $\mathrm{DT}_{50}$, the drying time (in hours) in which $50 \%$ of the plants died.

Laboratory screening tests with antidesiccant compounds. Twenty antidesiccant compounds (Table 1), including antitranspirants, fruit waxes and preservatives, and latex emulsions, were obtained from manufacturers or distributors. Initial tests determined the optimum concentration for reducing water loss from whole plants or stem sections. For a standard screening procedure, $10 \mathrm{~cm}$ stem sections were excised from 1-year-old hawthorn or maple seedlings and the cut ends sealed with melted paraffin wax. Stem segments $(n=S /$ compound $)$ were dipped into the antidesiccant solution, and the antidesiccant film was allowed to dry. Controls were dipped in water. Water loss was determined gravimetrically over $96 \mathrm{~h}$ of air drying. Internodal stem diameter was measured with a microcaliper and was used to calculate approximate surface area, assuming that the stem was nearly cylindrical. Water loss was then expressed on a surface area basis $\left(\mathrm{g} \mathrm{H}_{2} \mathrm{O} / \mathrm{cm}^{2}\right)$.

Greenhouse tests with antidesiccant compounds. In Mar. 199 1, eight compounds that performed well in screening tests were applied as a dip (roots and shoots) to 1-year-old hawthorn and maple seedlings $(n=10 /$ treatment $)$ that had been harvested in February and stored at 0C. Plants were air-dried for $48 \mathrm{~h}$, then potted and evaluated for survival and growth as described above. In addition, the number of days to budbreak was recorded for each plant.

Based on the results of the above experiments, 2-year-old hawthorn seedlings were either untreated or treated with Moisturin (Table 1) before or with Moisturin after being air dried for 0, 12, 24, or $48 \mathrm{~h}$. Moisturin (undiluted) was applied as a dip to the whole plant (roots and shoots). Five plants per treatment were used for each drying interval. After drying and determining water loss, plants were potted, grown in the greenhouse, and survival and growth were evaluated as above.

Field tests with antidesiccant compounds. An antitranspirant (AntiStress 2000), two waxes (Shield Brite AP-50C and Shield Brite AP-40), three concentrations of Moisturin (Table 1), and a covering of clear polyethylene $(0.1 \mathrm{~mm}$ thickness) were tested to determine the relative effectiveness on reducing water loss during field establishment of multistemmed Washington hawthorn trees. Antidesiccant compounds were sprayed to runoff on the tops (stems) of trees on 13 May 199 1. Plants were returned to $1 \mathrm{C}$ storage until planting. For the plastic wrap treatment, polyethylene was wrapped around the tops of trees at the time of planting and was removed after $\approx 6$ weeks. Two sets of 25 controls and 10 trees for each treatment were used. One set of trees was planted on 31 May 
and the other on 7 June in a sandy loam soil at Schmidt's nursery. Trees were not irrigated throughout the experiment, and no precipitation was recorded until 11 June. Weather conditions at the nursery following planting averaged 7/19C, 11/25C, 12/27C (minimum/maximum), and 82,12 , and $35 \mathrm{~mm}$ of rainfall during June, July, and August, respectively. Plants were evaluated for survival and dieback 90 days after planting.

Statistical analysis. Water loss and regrowth data were subjected to an analysis of variance using the general linear model (GLM) procedure of SAS (SAS Institute, 1985). Differences between treatment means were separated using Tukey's multiple range test at the $P=0.05$ level, except the days to budbreak data (Fig. 3) that were analyzed by determining the SE of the means of the replications for each treatment.

\section{Results}

Seasonal variation in desiccation tolerance of bare-root trees. The desiccation tolerance of bare-root trees varied with the date of harvest and the species (Fig. 1). Desiccation tolerance of all species was low during September and October, with $\mathrm{DT}_{50}$ 's of 8 to $12 \mathrm{~h}$. Desiccation tolerance of Norway maple increased slowly to a peak in January, that of Washington hawthorn changed little through January and reached a peak in February; tolerance of red oak rapidly increased in October and remained high through April (Fig. 1). Maximum desiccation tolerance for red oak was in January and February based on a lesser amount of stem dieback after $48 \mathrm{~h}$ of drying (data not shown). At maximum desiccation tolerance, hawthorn, maple, and oak had a $\mathrm{DT}_{50}$ of 24,48 , and $>48$ $\mathrm{h}$ of drying, respectively. Desiccation tolerance of Washington hawthorn seedlings decreased sharply to a $\mathrm{DT}_{50}$ of $\approx 2 \mathrm{~h}$ at the time when budbreak was observed (March) for field grown plants (Fig. 1).

The rate of water loss during a $48 \mathrm{~h}$ drying period for maple, oak,

Table 2. Water loss over $96 \mathrm{~h}$ from Norway maple and Washington hawthorn stem sections treated with film-forming compounds., ${ }^{z, y}$

\begin{tabular}{lll}
\hline & \multicolumn{1}{c}{ Water loss (milligrams water/cm ${ }^{2}$ per $\left.96 \mathrm{~h}\right)$} \\
\cline { 2 - 3 } Compound & Maple & Hawthorn \\
\hline None (control) & $23.2 \mathrm{a}$ & $28.2 \mathrm{ab}$ \\
Folicote & $22.2 \mathrm{a}$ & $23.6 \mathrm{abcde}$ \\
AntiStress 2000 (1:100) & $21.7 \mathrm{a}$ & $25.9 \mathrm{ab}$ \\
SemperFresh & $21.6 \mathrm{a}$ & $27.5 \mathrm{ab}$ \\
Cloudcover & $21.2 \mathrm{a}$ & $29.4 \mathrm{a}$ \\
Needlehold & $19.0 \mathrm{ab}$ & $27.1 \mathrm{ab}$ \\
Clearspray & $18.5 \mathrm{ab}$ & $23.3 \mathrm{abcde}$ \\
ForEverGreen & $18.4 \mathrm{ab}$ & $27.2 \mathrm{ab}$ \\
Decco A & $18.3 \mathrm{ab}$ & $29.9 \mathrm{a}$ \\
Fresh-Cote 214 & $18.0 \mathrm{ab}$ & $17.7 \mathrm{cdef}$ \\
Decco D & $17.6 \mathrm{ab}$ & $21.4 \mathrm{bcdef}$ \\
WiltPruf & $16.2 \mathrm{ab}$ & $29.6 \mathrm{a}$ \\
StaFresh 819 & $16.1 \mathrm{ab}$ & $21.2 \mathrm{bcdef}$ \\
VaporGard & $15.5 \mathrm{abc}$ & $24.2 \mathrm{abcd}$ \\
Shield Brite AP-50C & $15.4 \mathrm{abc}$ & $24.0 \mathrm{abcd}$ \\
Shield Brite C-280 & $14.3 \mathrm{abc}$ & $14.8 \mathrm{fg}$ \\
Fresh-Cote CW1 & $13.9 \mathrm{abc}$ & $16.0 \mathrm{efg}$ \\
Decco C & $13.2 \mathrm{abc}$ & $25.2 \mathrm{abc}$ \\
BPC \#1 & $10.4 \mathrm{bc}$ & $16.8 \mathrm{defg}$ \\
Moisturin (1:1) & $9.8 \mathrm{bc}$ & $9.7 \mathrm{gh}$ \\
Moisturin (undiluted) & $5.3 \mathrm{c}$ & $5.6 \mathrm{~h}$ \\
\hline War & &
\end{tabular}

${ }^{2}$ Water loss during 96h air-drying at $23 \pm 2 \mathrm{C}, 47 \pm 5 \% \mathrm{RH}$.

'Mean separation within columns using Tukey's multiple range test $P=$ 0.05 .

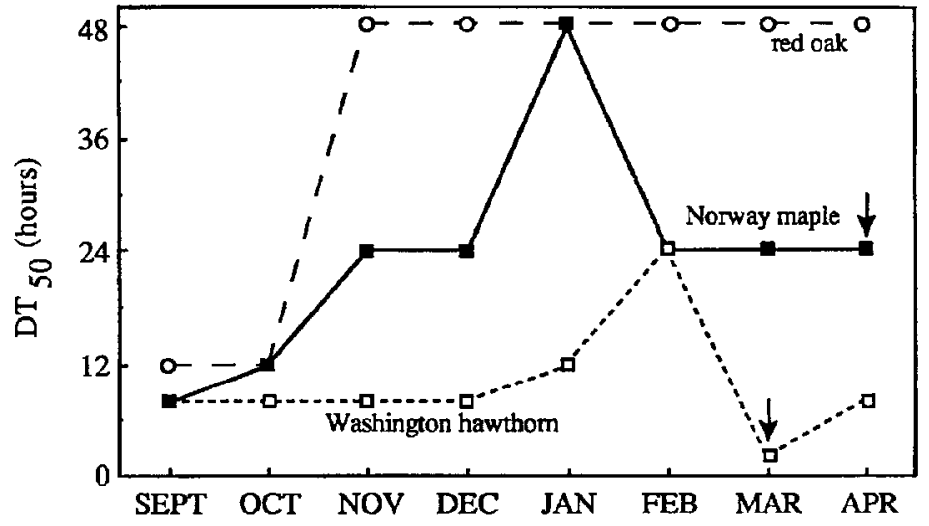

Fig. 1. Changes in desiccation tolerance (DT ${ }_{50}$, measured as the drying time at which $50 \%$ of the seedlings died) of field harvested l-year-old Norway maple, red oak, and Washington hawthorn seedlings. Survival was evaluated after 60 days. Arrows indicate approximate time of budbreak in the field.

and hawthorn seedlings harvested in February was similar, although, overall, hawthorn lost the most water and oak the least (Fig. 2). In contrast, the differences in survival and dieback/plant for each of the species were significant (Fig. 2). Washington hawthorn had suffered a substantial decrease in survival and increase in dieback by $24 \mathrm{~h}$ of air-drying, while this was not apparent for Norway maple or red oak seedlings until $48 \mathrm{~h}$ of air-

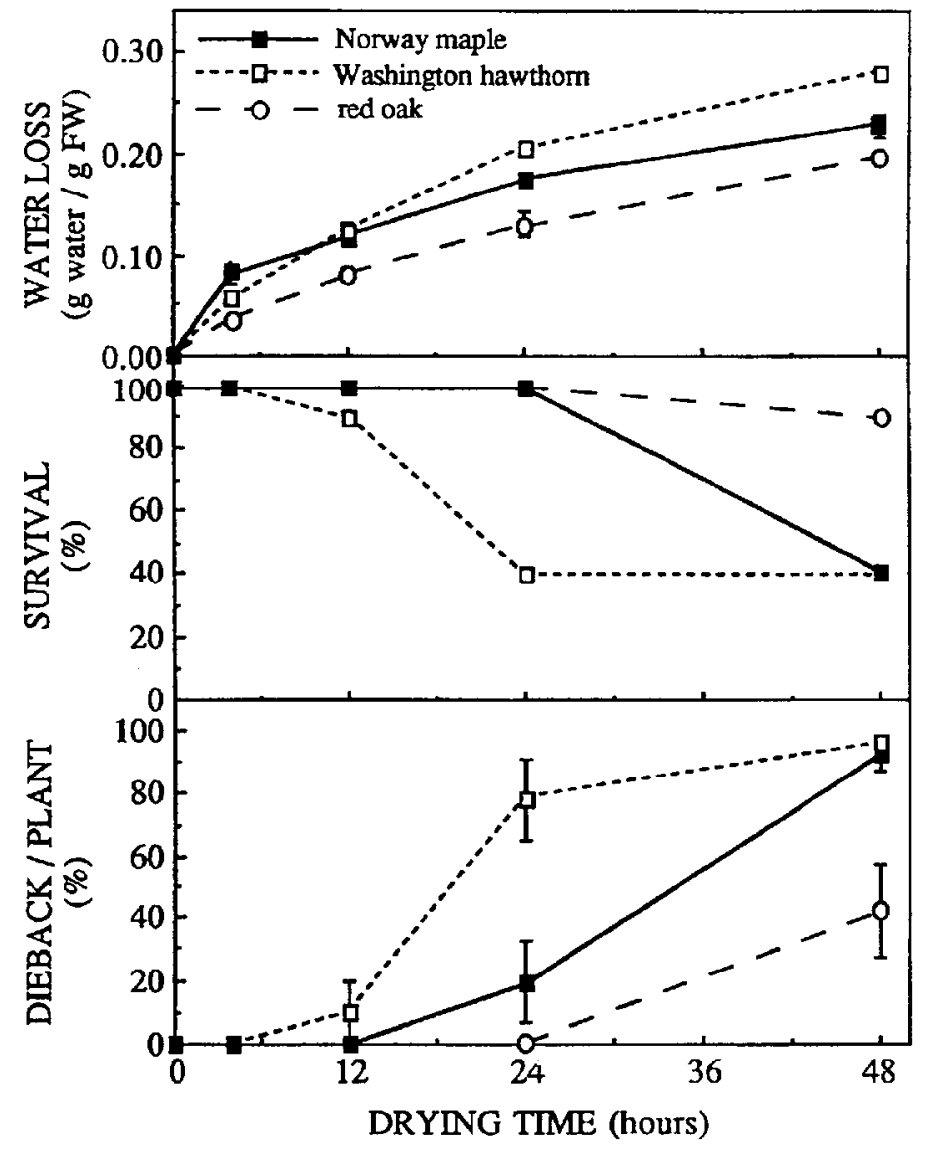

Fig. 2. Water loss and survival of February harvested bare-root seedlings after airdrying $(232 \mathrm{C}, 475 \% \mathrm{RH})$ on a laboratory bench for intervals up to $48 \mathrm{~h}$. Survival was evaluated by the number of plants that grew/total number of plants $(n=10)$ and the dieback/plant $(0=$ uppermost budbreak at the top of the stem, $100=$ dead $)$ after 60 days in the greenhouse. Vertical bars indicate SE. Lack of bars indicates low SE. 
Table 3. Water loss and regrowth of 1-year-old Norway maple and Washington hawthorn seedlings treated with film-forming compounds before $48 \mathrm{~h}$ of air-drying. ${ }^{2, y}$

\begin{tabular}{|c|c|c|c|c|}
\hline $\begin{array}{l}\text { Species \& } \\
\text { compound }\end{array}$ & Water loss ${ }^{x}$ & Survial $(\%)^{\mathrm{w}}$ & Dieback $(\%)^{\mathrm{v}}$ & Root growth rating $^{\prime \prime}$ \\
\hline \multicolumn{5}{|l|}{ Norway maple } \\
\hline None (control) & $0.186 \mathrm{a}$ & 80 & $52 a$ & $2.8 \mathrm{ab}$ \\
\hline $\mathrm{BPC} \# 1$ & $0.1713 \mathrm{ab}$ & 100 & $29 \mathrm{ab}$ & $3.3 \mathrm{ab}$ \\
\hline Decco C & $0.162 \mathrm{abc}$ & 90 & $34 a b$ & $2.9 \mathrm{ab}$ \\
\hline Decco A & $0.161 \mathrm{abc}$ & 100 & $28 a b$ & $3.5 \mathrm{ab}$ \\
\hline Shield Brite AP-50C & $0.158 \mathrm{abcd}$ & 90 & $38 \mathrm{ab}$ & $2.3 \mathrm{ab}$ \\
\hline Moisturin (1:1) & $0.136 \mathrm{bcd}$ & 100 & $\mathrm{Ob}$ & $4.1 \mathrm{~b}$ \\
\hline Shield Brite C-280 & $0.128 \mathrm{~cd}$ & 100 & $54 \mathrm{a}$ & $3.3 \mathrm{ab}$ \\
\hline Fresh-Cote CW1 & $0.112 \mathrm{~d}$ & 100 & $14 \mathrm{ab}$ & $1.7 \mathfrak{a}$ \\
\hline Moisturin (undiluted) & $0.072 \mathrm{e}$ & 100 & $0 \mathrm{~b}$ & $4.5 \mathrm{~b}$ \\
\hline \multicolumn{5}{|l|}{ Washington hawthom } \\
\hline None (control) & $0.279 \mathrm{a}$ & $.10 \mathrm{a}$ & $99 a$ & $0.0 \mathrm{a}$ \\
\hline Decco C & $0.248 \mathrm{ab}$ & $50 \mathrm{ab}$ & $95 a$ & $1.0 \mathrm{ab}$ \\
\hline Decco A & $0.235 \mathrm{bc}$ & $80 \mathrm{~b}$ & $94 \mathrm{a}$ & $1.6 \mathrm{abcd}$ \\
\hline Shield Brite AP-50C & 0.199 & $80 \mathrm{~b}$ & $88 a$ & $1.6 \mathrm{abcd}$ \\
\hline Fresh-Cote CW1 & $0.179 \mathrm{de}$ & $50 \mathrm{ab}$ & $87 \mathrm{a}$ & $1.1 \mathrm{abc}$ \\
\hline Shield Brite C. -280 & $0.175 \mathrm{de}$ & $70 \mathrm{ab}$ & 93 a & 1.2 abcd \\
\hline $\mathrm{BPC} \# 1$ & 0.161 & $80 \mathrm{~b}$ & 88 a & $2.4 \mathrm{bcd}$ \\
\hline Moisturin (1:1) & $0.130 \mathrm{f}$ & $80 \mathrm{~b}$ & $43 \mathrm{~b}$ & $3.1 \mathrm{~d}$ \\
\hline Moisturin (undiluted) & $0.092 \mathrm{~g}$ & $80 \mathrm{~b}$ & $25 \mathrm{~b}$ & $3.0 \mathrm{~cd}$ \\
\hline $\begin{array}{l}{ }^{7} \text { Water loss during } 48 \mathrm{~h} \text { a } \\
{ }^{y} \text { Mean separation within } \\
{ }^{\circ} \text { grams water loss/grams } \mathrm{f} \\
\text { "Percent survival: Number } \\
60 \text { days. } \\
\text { "Percent dieback/plant: } 0\end{array}$ & $\begin{array}{l}\text { air-drying at } 23 \\
\text { columns using } \\
\text { fresh weight } p \\
\text { of plants tha }\end{array}$ & $\begin{array}{l} \pm 2 \mathrm{C}, 47 \pm 5 \\
\text { Tukey's multi } \\
\text { at } 48 \mathrm{~h} \text {. } \\
\text { arew/total nu }\end{array}$ & $\begin{array}{l}\text { RH. } \\
\text { range test, } P= \\
\text { ber of plants ( }\end{array}$ & $\begin{aligned} & 0.05 . \\
= & 10), \text { evaluated after }\end{aligned}$ \\
\hline
\end{tabular}

drying. Red oak seedlings had the highest survival and lowest dieback after $48 \mathrm{~h}$ of air-drying.

Laboratory screening of antidesiccant compounds. Most of the compounds tested in this study did not significantly reduce water loss from hawthorn and maple stem segments compared to untreated stem segments (Table 2). Only BPC \#1 and the two Moisturin formulations significantly reduced water loss from maple stems compared to controls, but these treatments were not significantly different from many of the other antidesiccant treatments. Similarly, many of the compounds applied to hawthorn stem segments were not significantly different from controls or from each other (Table 2). In contrast to the results with maple, the 1: 1 dilution of Moisturin was more effective in reducing water loss than most other treatments, while undiluted Moisturin was significantly more effective than all other non-Moisturin treatments. The effectiveness of the various compounds in reducing water loss from stem segments was different between maple and hawthorns. Control and treated hawthorn stems generally lost more water over $96 \mathrm{~h}$ of air-drying than maple stems, except in the case of Moisturin, where water loss was similar for both species.

Greenhouse tests with antidesiccant compounds. Of the antidesiccant treatments applied to 1-year-old maple and hawthorn seedlings before $48 \mathrm{~h}$ of air-drying, Moisturin (undiluted) was most effective in significantly reducing water loss (Table 3). Moisturin (1:1) was also more effective than all other treatments except BPC \#1 in reducing water loss from hawthorn seedlings. Several of the treatments had similar survival rates, however, dieback/plant and root growth ratings differed among treatments (Table 3, Fig. 3). Moisturin-treated hawthorn seedlings had significantly less dieback/plant than all other treatments. Ratings of root growth for hawthorn and maple seedlings, and dieback/plant for maple seedlings, were most favorable for Moisturin-treated plants, though they were not always significantly higher than those for other treatments. Although there were significant differences in water loss between plants treated with Moisturin (undiluted) and Moisturin 1:1, survival, dieback/plant, and root growth were similar for both treatments (Table 3).

There were few or no visible symptoms of phytotoxicity on maple and hawthorn plants from the antidesiccant treatments, except for BPC \#1 and Shield Brite C-280, which occasionally caused dark patches on the stems. Antidesiccant-treated seedlings broke bud -1 week earlier than untreated seedlings, except for Moisturin treated hawthorns (Fig. 4), which broke bud 14 to 21 days earlier than plants of other treatments and 28 days earlier than the controls (Fig. 4). None of the antidesiccant treatments adversely affected budbreak and new shoot growth. Occasionally, the emerging shoots were slightly distorted but soon straightened and grew normally. The roots had grown through the antidesiccant coating regardless of treatment.

In tests of Moisturin on 2-year-old seedlings, the results were similar to those with 1-year-old seedlings. Plants treated with Moisturin (undiluted) before $48 \mathrm{~h}$ of drying survived (Fig. 5B), whereas untreated plants did not survive even $12 \mathrm{~h}$ of drying (Fig. 5A). Plants dried for $12 \mathrm{~h}$ and then treated with Moisturin also showed improved establishment and survival (Fig. 5C). During 48 $\mathrm{h}$ of air-drying, plants treated with Moisturin before drying lost $>50 \%$ less water than untreated plants (data not shown).

Field tests with antidesiccant compounds. Results of field testing was similar to the results found in laboratory and greenhouse experiments. For the 31 May planting, hawthorn trees treated with 


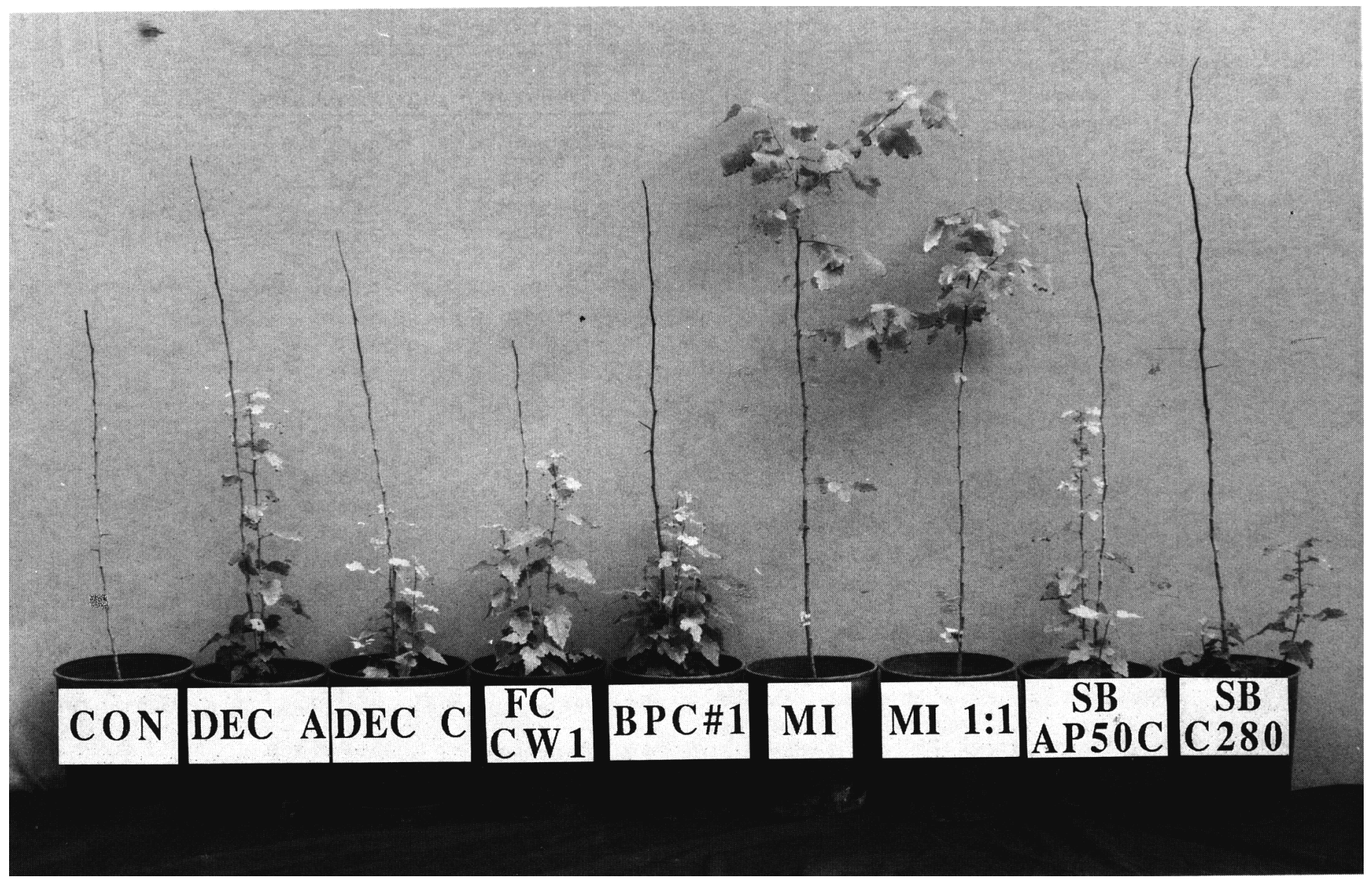

Fig. 3. One-year-old hawthorn seedlings grown for 90 days in a greenhouse after treatment with antidesiccant compounds and $48 \mathrm{~h}$-drying on a laboratory bench. Abbreviations: $\mathrm{CON}=$ control, $\mathrm{DEC}=\mathrm{Decco}, \mathrm{FC}=$ Fresh-Cote, $\mathrm{MI}=$ Moisturin, $\mathrm{SB}=$ Shield Bone

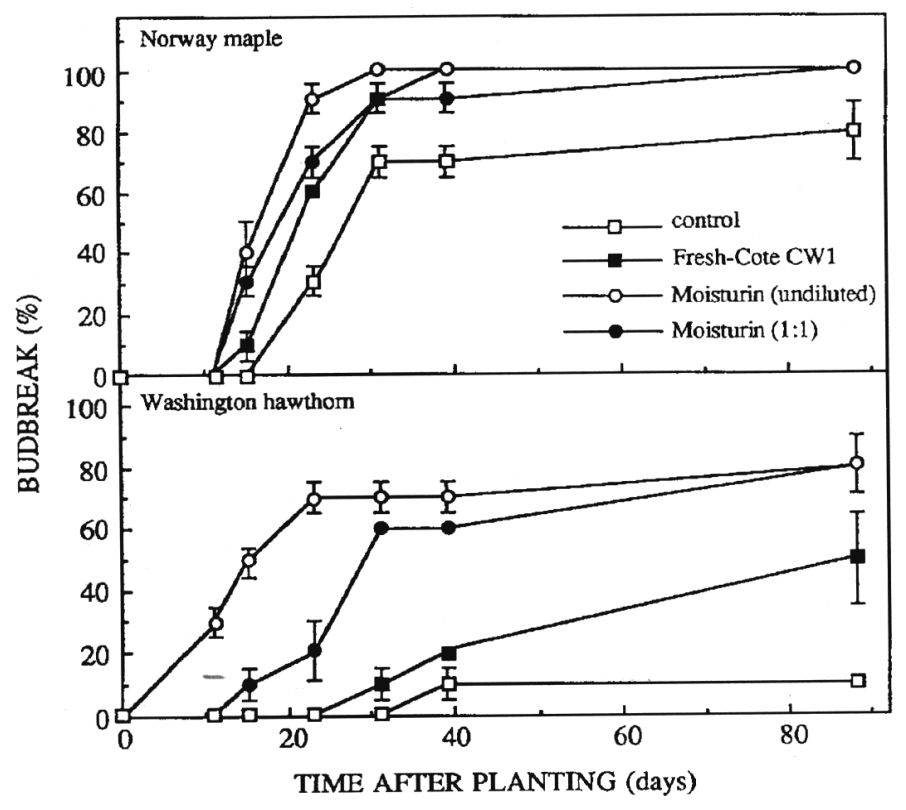

Fig. 4. Differences in the timing of budbreak of Norway maple and Washington hawthorn seedlings treated with antidesiccants. Fresh-Cote CW1 data are representative of the other treatments (see Fig. 3) not included in the figure. Antidesiccants were applied before $48 \mathrm{~h}$ of air-drying as described in Table 3. Budbreak [plants breaking bud/total number of plants $(n=10)$ ] at 88 days equals survival (\%) in Table 3. Vertical barsindicate SE. Lack of bars indicates low SE. any of the three Moisturin concentrations had higher survival (average of 93\%) and a lower dieback (average of 8\%) than other treatments or untreated plants, although most of the differences were not statistically significant (Table 4). However, Moisturin treated plants (especially Moisturin undiluted) broke bud sooner, more uniformly, and more often at the top of the stem than did plants of other treatments (Fig. 6). Trees planted on 7 June had lower survival and more dieback/plant than those planted May 31, but the trends were similar for both planting dates (Table 4).

\section{Discussion}

Of the species tested, bare-root red oak trees appear to be the most tolerant of desiccation stress, followed by Norway maple and Washington hawthorn (Fig. 1). The large differences in desiccation tolerance between Norway maple and Washington hawthorn seedlings (Figs. 1 and 2) were similar to those reported by Murakami et al. (1990). Insley and Buckley (1985) speculated that the coarser root system of Fraxinus angustifolia Vahl. seedlings contributed to its higher desiccation tolerance as compared to Betula pubescens seedlings. Red oak had the coarsest root system of the three species examined in our study. Larger roots would have a lower surface area to volume ratio, which would possibly be responsible for the slower rate of water loss and the ability to survive longer exposure to desiccation. On several of the harvest dates, the stem of red oak seedlings had died completely after extreme drying, but shoots were regenerated from adventitious buds located below the root 


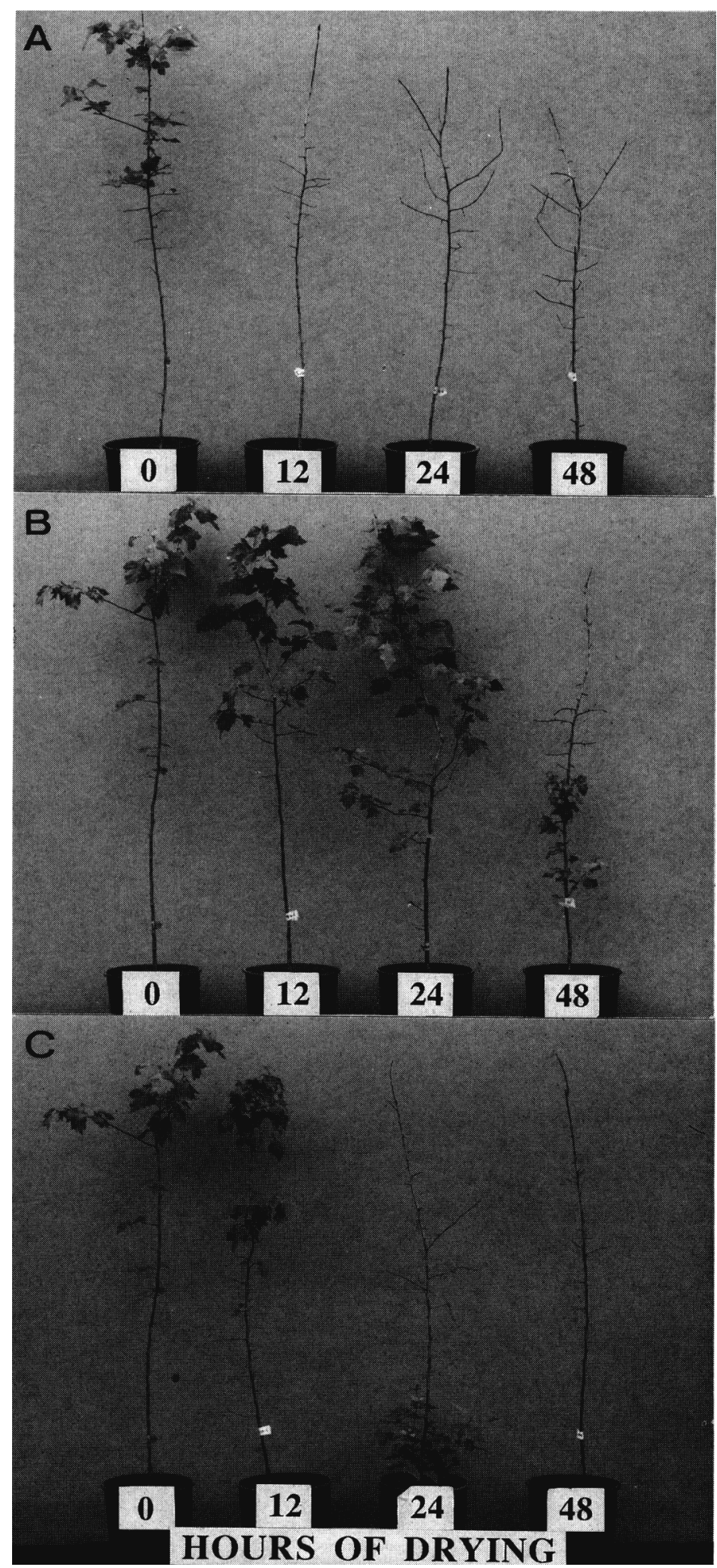

Fig. 5. Two-year-old hawthorn seedlings untreated (controls) (A), treated with Moisturin (undiluted) before air-drying (B), or treated with Moisturin (undiluted) after air-drying $(\mathrm{C})$. Air-drying $(23 \pm 2 \mathrm{C}, 475 \% \mathrm{RH})$ was on a laboratory bench for $0,12,24$, or $48 \mathrm{~h}$. After drying, plants were potted and placed in a greenhouse to evaluate survival.

collar. Plants that exhibited budbreak below the root collar often showed sparse root growth, reflecting the poor regeneration of roots, which is common to red oaks (Struve, 1990).

Maximum desiccation tolerance of all three species occurred during January or February (Fig. 1). Red oak trees harvested in January and February, air-dried for $48 \mathrm{~h}$, and then evaluated for survival, had less stem dieback than plants harvested before or after these months (data not presented). Presumably, this result was due to the greater desiccation tolerance of stem or root tissues during these months. Ritchie et al. (1985) found that lodgepole pine (Pinus contorta Dougl.) and interior spruce (Picea glauca engelmunnii complex) seedlings harvested from 15 Nov. to 28 Feb. near Armstrong B.C., Canada, were more tolerant of a $60 \mathrm{~min}$ drying interval $(30 \mathrm{C}, 50 \% \mathrm{RH})$ than seedlings harvested before or after this time. Various physiological changes occurring during this period, such as changes in dormancy, cold hardiness, and tissue water content, have been proposed as being important in the success of handling bare-root hardwoods (Murakami et al., 1990) and conifer species (Ritchie et al., 1985; Ritchie and Shula, 1984; Tyree et al., 1978). Success of postharvest handling would likely be improved by harvesting when plants are most desiccation tolerant. In the case of Washington hawthorn, the improvement in survival and re-establishment performance when harvested during February may be due to the higher level of desiccation tolerance (Fig. 1). Desiccation tolerance apparently decreases rapidly after budbreak occurs and new shoots have developed. Washington hawthorn seedlings harvested shortly after budbreak in the field (March), when new shoots were $\approx 1 \mathrm{~cm}$ long, only survived $2 \mathrm{~h}$ of air-drying. Desiccation tolerance increased slightly at the April harvest, probably due to hardening off of new shoots (Fig. 1).

Of the antidesiccant products tested in this study, Moisturin was the most effective in reducing water loss from stem segments (Table 2) and seedlings (Table 3) and in improving transplant survival and regrowth in the greenhouse (Table 3, Figs. 3 and 4) and field (Table 4, Fig. 6) studies. Moisturin was most effective when applied to 1- and 2-year-old hawthorn seedlings before desiccation stress was encountered (Table 3, Figs. 3 and 5B). However, application of Moisturin after mild desiccation stress improved transplant survival of 2-year-old hawthorns dried for 12 h (Fig. 5C) and that of multistemmed hawthorn trees after 5 months of cold storage (Table 4, Fig. 6). This occurred probably by reducing water loss and allowing the roots to compensate for water loss during establishment in the growing medium.

None of the antitranspirant compounds tested in this study were effective in reducing water loss from maple or hawthorn stem section (Table 2). Antitranspirants have in general been inconsistent in reducing water loss when applied to the foliage of deciduous and conifer trees (Hummel, 1990; Simpson, 1984). Otherresearchers have found that some antitranspirants, such as WiltPruf, were effective in reducing water loss from potted defoliated hardwood seedlings and slightly improving the survival of defoliated barerooted hardwood seedlings following transplanting in midsummer (Sulaiman, 1968). These transplanting studies were conducted without exposing the bare-root plants to severe drying stress during handling, and it is not known what effect more severe water stress conditions would have on the performance of trees treated with antitranspirant compounds. In our studies, antitranspirant compounds did not significantly reduce water loss from maple of hawthorn stems during $96 \mathrm{~h}$ of drying. In our whole-plant studies, Washington hawthorn trees were subjected to $48 \mathrm{~h}$ of drying stress, which is normally enough to kill seedlings harvested in midwinter (Fig. 1), but treatment of the entire plant (roots and shoots) with waxes and latex coatings before such drying resulted in high survival, while untreated plants died (Table 3).

The thickness of the film formed by the compounds when they had dried on the bark may have been influential in their success in reducing stem dieback. A thick uniform coverage, especially on 


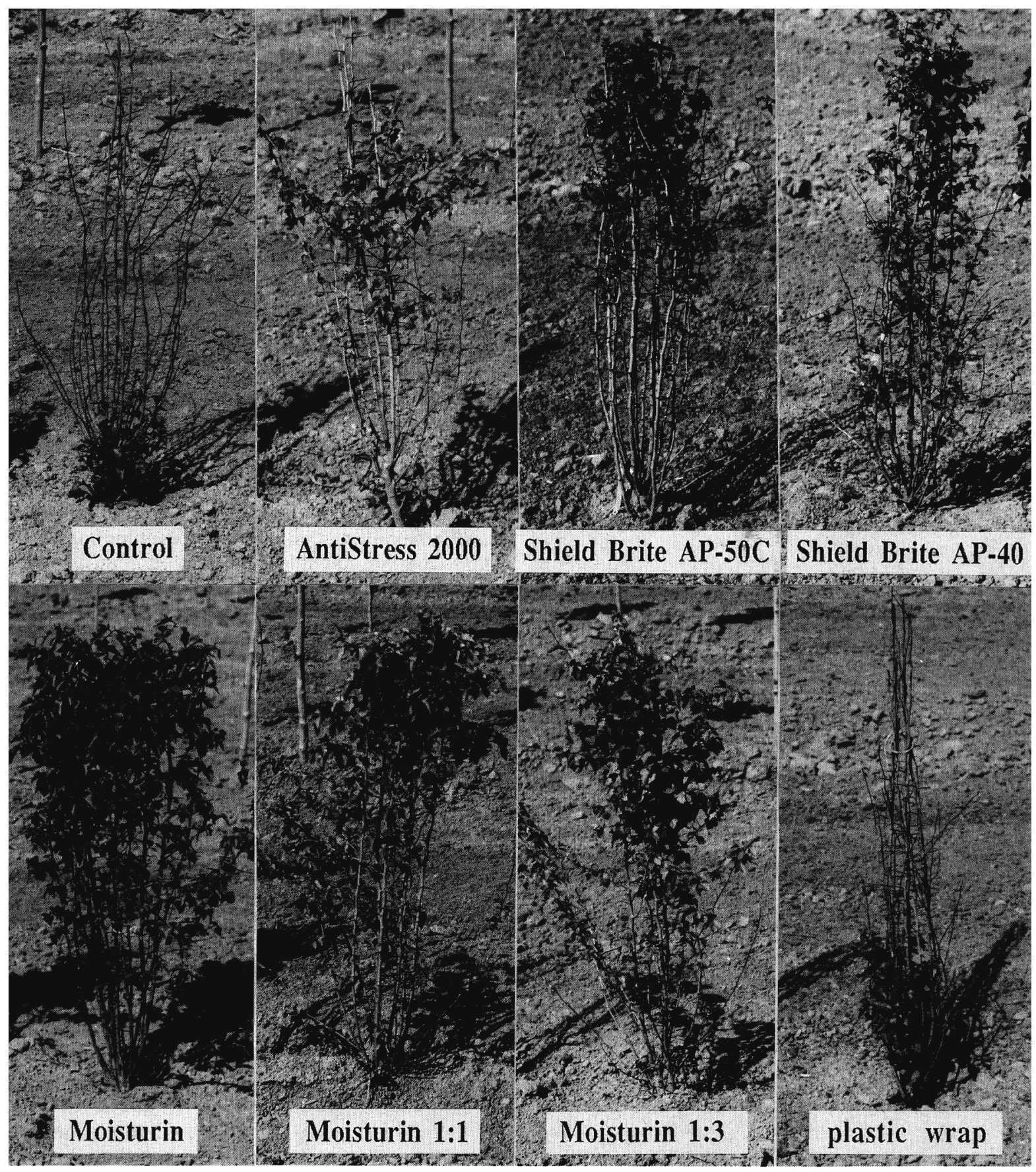

Fig. 6. Multistemmed hawthorn trees treated with antidesiccant compounds applied to the stems as a spray before planting or wrapped in polyethylene plastic at the time of planting. Photos 75 days after field planting, which was 31 May.

rough-barked plants such as Washington hawthorn, presumably would be more effective in reducing water loss than a thin nonuniform film. Moisturin (undiluted) had obviously formed a thicker coating on the bark than any other compound. However, the 1:3 dilution of Moisturin used in field testing approached the consistency of several of the waxes and antitranspirants, but was generally more effective than the other compounds tested in improving survival and regrowth (Table 4, Fig. 6). Increasing the concentration of antitranspirants in preliminary studies did not reduce water loss and, in several cases, actually increased it (data not shown).
For species that are less sensitive to desiccation stress, such as red oak and Norway maple, harvesting bare-root plants at maximum desiccation tolerance may be adequate to ensure satisfactory survival. However, species such as Washington hawthorn, which do not develop a high level of desiccation tolerance, require special care to attain acceptable levels of establishment after planting. Harvesting when desiccation tolerance is at a maximum, and the use of effective antidesiccant compounds, may be necessary for maximizing the success of postharvest handling. Additional tests are necessary to determine if these treatments may be applicable to 
Table 4. Field testing of film-forming compounds applied to multistemmed hawthorn trees during re-establishment. ${ }^{\text {zy }}$

\begin{tabular}{lccccc}
\hline \hline & \multicolumn{2}{c}{ 31 May planting } & & \multicolumn{2}{c}{ 7 June planting } \\
\cline { 2 - 3 } \cline { 5 - 6 } Protectant & Survival(\%) & Dieback (\%) & & Survival (\%) & Dieback (\%) \\
\hline Wrapped in polyethylene & 70 & $90 \mathrm{a}$ & & 100 & $90 \mathrm{a}$ \\
None (control) & 80 & $63 \mathrm{ab}$ & & 36 & $78 \mathrm{ab}$ \\
Shield Brite AP-40 & 70 & $43 \mathrm{bc}$ & & 20 & $71 \mathrm{ab}$ \\
Shield Brite AP-50C & 70 & $22 \mathrm{c}$ & & 20 & $74 \mathrm{ab}$ \\
AntiStress 2000 (1:100) & 80 & $18 \mathrm{c}$ & & 80 & $59 \mathrm{abc}$ \\
Moisturin (1:1) & 100 & $11 \mathrm{c}$ & & 50 & $22 \mathrm{c}$ \\
Moisturin (undiluted) & 100 & $9 \mathrm{c}$ & & 44 & $31 \mathrm{bc}$ \\
Moisturin (1:3) & 80 & $5 \mathrm{c}$ & & 80 & $43 \mathrm{abc}$
\end{tabular}

Plants evaluated on 27 Aug. 1991.

'Mean separation within columns using Tukey's multiple range test, $P=0.05$.

'Percent survival: Number of plants that grew/total number of plants $(n=25$ for controls, $n=10$ for each treatment on each planting date, except for Moisturin (undiluted) treated plants on 7 June planting where $\mathrm{n}=9$ ).

other desiccation sensitive species. The effectiveness of Moisturin in both reducing water loss and improving survival of Washington hawthorn trees in laboratory, greenhouse, and field studies further supports the notion that desiccation stress during postharvest handling and establishment is the major cause of poor establishment.

\section{Literature Cited}

Hummel, R.L. 1990. Water relations of container-grown woody and herbaceous plants following antitranspirant sprays. HortScience 25:772775 .

Insley, H. and G.P. Buckley. 1985. The influence of desiccation and root pruning on the survival and growth of broadleaved seedlings. J. Hort. Sci. 60(3):377-387.

Kozlowski, T.T. and W.J. Davies. 1975. Control of water balance in transplanted trees. J. Arboriculture 1(1):1-10.

Lefevre, R.E., A.C. Cameron, and N.C. Peterson. 1991. Influence of moisture loss during storage and new growth of conifer seedlings. J. Environ. Hort. 9(2):92-96.

Lyle, E.W. 1955. Hot waxing of rose bushes for store trade. Amer. Rose Arm. 40:113-115.

Mulling, R.E. and W.R. Bunting. 1979. Another look at clay dipping of bare-root nursery stock. For. Chronicle 55(5):183-188.

Murakami, P., T.H.H. Chen, and L.H. Fuchigami. 1990. Desiccation tolerance of deciduous plants during postharvest handling. J. Environ. Hort. 8(1):22-25.

Ritchie, G.A., J.R. Roden, and N. Kleyn. 1985. Physiological quality of lodgepole pine and interior spruce seedlings: Effects of lift dates and duration of freezer storage. Can. J. For. Res. 15:636-645.

Ritchie, G.A. and R.G. Shula. 1984. Seasonal changes in tissue-water relations in shoot and root systems of Douglas-fir seedlings. For. Sci. 30(2):538-548

SAS Institute. 1985. SAS/STAT guide for personal computers, version 6 (ed.). SAS Institute, Inc., Cary, N.C.

Simpson, D.G. 1984. Filmforming antitranspirants: Their effect on root growth capacity, storability, moisture stress avoidance, and field performance of containerized seedlings. For. Chronicle 60(6):335-339.

Struve, D.K. 1990. Root regeneration in transplanted deciduous nursery stock. HortScience 25:266-270.

Sulaiman, A.S. 1968. A study of the desiccation and the effects of antidesiccants on water loss through the foliage and bark of five species of hardwood planting stock. PhD Diss., North Carolina State Univ., Raleigh. (Diss. Abstr. 68-13479).

Tukey, H.B. and K. Base. 1931. The effect of paraffining, pruning, and other storage treatments upon the growth of roses and cherry trees. Proc. Amer. Soc. Hort. Sci. 28:489-495.

Tyree, M.T., Y.N.S. Cheung, M.E. MacGregor, and A.J.B. Talbot. 1978. The characteristics of seasonal and ontogenetic changes in the tissuewater relations of Acer, Populus, Tsuga, and Picea. Can. J. Bot. 56:635647. 